\title{
Analisis Promosi Jabatan Berbasis Kesetaraan Gender Pada Birokrasi Pemerintahan
}

\author{
Mukhammad Luckyto \\ IAIN Kudus, Kudus, Indonesia \\ mukhammadlucky24@gmail.com \\ Sinka Oktaviana \\ IAIN Kudus, Kudus, Indonesia \\ sinkaoktav@gmail.com.com \\ Laily Fu'adah \\ IAIN Kudus, Kudus, Indonesia \\ lailyfuadah17@gmail.com
}

\begin{abstract}
Gender is a social construction or form so that it can be formed or changed according to place, time or age, ethnicity, race, culture, social status, religious understanding, country, ideology, politics, law and economy. The purpose of this study was to analyze the promotion of positions with the perspective of gender equality both men and women in the government bureaucracy. The method used in this study is a library research method using a descriptive analysis approach. The result of this study is that the role or participation of women in the government bureaucratic structure has exceeded that of men and has experienced gender justice or equality, but there is still a small gap between female civil servants who are difficult for echelon pratama positions.
\end{abstract}

Keywords: Job Promotion; Gender Equality; Government Bureaucracy 


\begin{abstract}
Abstrak
Gender merupakan suatu kontruksi atau bentuk sosial sehingga dapat dibentuk atau diubah sesuai tempat, waktu atau zaman, suku, ras, budaya, status sosial, pemahaman agama, engara, ideologi, politik, hukum serta ekonomi. Tujuan penelitian ini adalah untuk menganalisis promosi jabatan dengan perspektif kesetaraan gender baik laki-laki maupun perempuan pada birokrasi pemerintahan. Metode yang digunakan dalam penelitian ini adalah metode studi pustaka atau library research dengan menggunakan pendekatan analiisis deskriptif. Hasil Penelitian ini adalah peran atau partsipasi perempuan terhadap struktur birokasi pemerintahan telah banyak melebihi laki-laki serta mengalami keadilan atau kesetaraan gender, akan tetapi masih sedikit kesenjangan PNS perempuan sulit untuk jabatan eselon pratama.
\end{abstract}

Kata kunci: Promosi Jabatan; Kesetaraan Gender; Biroksi Pemerintah

\title{
A. Pendahuluan
}

Pancasila dan UUD 1945 telah memberikan hak yang sama terhadap laki-laki maupun perempuan agar dapat ikut serta berperan dalam melaksanakan pembangunan dan menikmati hasilnya, termasuk pembangunan aparatur pemerintahan. Kesempatan dan perlakuan yang sama antara laki-laki dan perempuan dalam pekerjaan juga terkandung dalam UU Ketenagakerjaan No. 13 Tahun 2003 yang memaparkan bahwasannya setiap tenaga kerja memiliki kesempatan yang sama untuk mendaoatkan pekerjaan tanpa adanya diskriminasi. Sejak saat itu, isu gender menjadi salah satu hal penting yang tertuang dalam berbagai dokumen perencanaan pembangunan, baik secara nasional maupun global. Isu gender juga disebutkan dalam tujuan pembangunan berkelanjutan/sustainable Development Goals (SDGs), pada poin kelima yang memaparkan pencapaian kesetaraan gender dan pemberdayaan perempuan (Sari, Raharjo, \& Rahmawati, 2018).

Kesetaraan gender muncul tatkala kaum laki-laki dan perempuan yang telah memiliki keadaan serta kedudukan yang sama dalam mendapatkan peluang dan hak sebagai seorang manusia, yang mampu berperan dan berpartisipasi dalam kegiatan ekonomi, politik, sosial budaya, pendidikan, pertahanan dan keamanan negara. Adanya kesetaraan gender dan keadilan gender ditandai oleh tidak adanya diskriminasi antara kaum perempuan dan laki-laki, yang memberikan kebebasan dalam partisipasi dan pengendalian atas pembangunan serta pencapaian manfaat yang setara atau sama. (Sahirah, Setiawan, \& Burhanuddin, 2015). Pada tingkat pekerja, terutama pekerja perempuan, penting untuk mendorong adanya kesetaraan antara laki-laki dan 
perempuan dalam hal mencari pekerjaan yang lebih layak. Salah satu cara untuk memastikan tidak adanya kesenjangan jabatan antara laki-laki dan perempuan adalah dengan melakukan promosi jabatan dalam birokrasi pemerintahan. Promosi jabatan merupakan salah satu aktivitas manajemen organisasi, yang bertujuan untuk mengembangkan sumber daya manusia dalam suatu organisasi tersebut. Promosi jabatan seorang Pegawai Negeri Sipil (PNS), diselenggarakan berdasaran ketentuan hukum perundang-undangan yakni UU Nomor 5 Tahun 2014 yang mengatur tentang keberadaan PNS sebagai Aparatur Sipil Negara (Kadarisman, 2013).

Terkait hal diatas, isu kesetaraan gender tetap belum mencapai kondisi optimal pada bidang kehidupan terutama dalam birokrasi pemerintahan walaupun tingkat partisipasi PNS perempuan pada tahun 2020 lebih banyak dibandingkan partisipasi PNS laki-laki dengan partisipasi PNS perempuan mencapai 51,71\% sedangkan partisipasi PNS laki-laki hanya 48,29\% yang menandakan bahwa kesetaraan gender sudah mulai terlihat nyata dalam birokrasi pemerintahan namun, jika dilihat pada promosi jabatan, seorang PNS laki-laki jauh lebih unggul dibandingkan PNS perempuan. Hal ini dibuktikan dengan ditemukannya banyak permasalahan kesetaraan gender terkait jabatan pada birokrasi pemerintahan, salah satunya yang disebutkan dalam Humas BKN yang telah melakukan survei kepada perempuan di birokrasi Kemenppa dengan mencatat tingkat partisipasi pada jabatan struktural yang tersedia di pemerintahan. Dalam survei ini, tingkat partisipasi ASN perempuan jauh lebih rendah dibandingkan tingkat partisipasi ASN laki-laki pada birokrasi pemerintahan dimana tercatat ASN perempuan hanya menempati tingkat partisipasi jabatan di birokrasi pemerintahan sebesar 22\%, sementara ASN laki-laki menempati sebesar tingkat partisipasi jabatan di birokrasi pemerintahan 78\% (https://www.bkn.go.id).

Kemudian hal yang sama diungkapkan Badan Pusat Statistik (BPS) Indonesia, tahun 2019-2020, PNS laki-laki mempunyai tingkatan pangkat atau golongan Eselon 1 lebih banyak dibandingkan PNS perempuan dengan tingkat partisipasi PNS laki-laki pada jabatan Eselon 1 mencapai 512 jiwa sedangkan tingkat paertisipasi PNS pada jabatan Eselon 1 hanya mencapai 113 jiwa pada tahun 2019. Sedangkan pada tahun 2020, tingkat partisipasi PNS perempuan pada pangkat atau golongan Eselon 1 mengalami penurunan dengan hanya mencapai 9 jiwa saja sedangkan tingkat partisipasi PNS laki-laki pada pangkat atau golongan Eselon 1 mengalami peningkatan dengan mencapai 498 jiwa. Hal ini menunjukkan masih terjadi kesetaraan gender belum mencapai optimal pada bidang promosi jabatan dalam birokrasi pemerintah (https://bps.go.id/indikator/indikator/view_data_pub/0000/api_pub/TEJrTHhZODZmS XhoblFvSGtlbkFMQT09/da_02/1) 
Jabatan struktural adalah posisi yang menunjukkan tugas, tanggung jawab, wewenang dan hak PNS dalam rangka memimpin suatu organisasi negara. Tingkat jabatan struktural biasanya dikenal dengan istilah Eselon. Setiap eselon dalam jabatan struktural, terdiri atas tingkatan terendah hingga tingkatan paling tinggi (mulai tingkat $\mathrm{V} / \mathrm{b}$ sampai I/a). Jabatan struktural merupakan jabatan organisasi dalam birokrasi pemerintahan baik di pusat maupun daerah. Sehingga hal ini dapat membuat para pegawai berusaha untuk mendapatkan promosi jabatan, (Silalahi, Rachmawati, \& Bernadus, 2016), mengingat peran atau partisipasi PNS perempuan dalam birokrasi pemerintah pada tahun 2020 lebih tinggi dari PNS laki-laki namun, kenyataanya dalam promosi jawaban PNS perempuan jauh tertinggal dari PNS laki-laki.

Hal tersebut dapat terjadi dikarenakan beberapa adanya faktor penyebab, salah satunya dari segi kualifikasi, PNS perempuan memiliki kualifikasi yang lebih rendah daripada PNS laki-laki, terutama pada jenjang S2 dan S3 padahal untuk meningkatkan kualifikasi PNS, pemerintah sudah memberikan izin belajar bagi PNS namun tetap saja dalam promosi jabatan, PNS perempuan masih tertinggal dengan PNS laki-laki. Untuk itu, penelitian ini mencoba menganalisis sejauh mana pengaruh kesetaraan gender dalam promosi jabatan. Dengan adanya penelitian ini, peneliti yakin bahwa penelitian ini akan dapat memberikan impact yang berbeda dalam pemahaman isu kesetaraan gender dalam promosi jabatan pada birokrasi pemerintah. Dan penelitian ini juga diharapkan membangun kerangka diskusi yang baru terkait konsep kesetaraan gender dalam promosi jabatan pada birokrasi pemerintahan.

\section{B. Pembahasan}

Berisi Dasar promosi jebatan yang umum digunakan oleh setiap institusi baik publik maupun privat didasarkan atas prestasi kerja dan senoritas. Dalam melakukan analisis terkait kesetaraan gender dalam promosi jabatan dibidang birokrasi. Aspekaspek dianalisis berupa: prestasi kerja, senoritas, kompetensi dan kualifikasi.

\section{Prestasi Kerja}

\section{a. Sasaran Kinerja Pegawai (SKP)}

Promosi jabatan di dalam instansi pemerintah baik dipusat maupun daerah merupakan bagian kegiatan pengembangan karir PNS, ditegaskan dalam pasal 177 ayat 1 PP Nomor 11 Tahun 2017 tentang Pegawai Negeri Sipil. Selanjutnya pada ayat 2, dikatakan manajemen pengembangan karir PNS dapat melakukan melalui mutasi pegawai atau promosi. Berdasarkan ketentuan UU diatas, Negara telah menegaskan bahwa tidak ada diskriminasi gender dalam mendapatkan promosi jabatan, artinya 
perempuan mempunyai kesempatan yang sama dengan laki-lakis epanjang memenuhi kriteria dan persyaratan yang berlaku.

Dasar penilaian prestasi kerja yang seharusnya diukur dari nilai capaian Sasaran kinerja Pegawai (SKP) untuk saat ini, belum bisa digunakan sebagai dasar untuk mengukur tingkat prestasi kerja seorang PNS, karena validitas datanya masih lemah. SKP tidak bisa diharapkan PNS perempuan dalam birokrasi pemerintahan untuk mendapatkan promosi jabatan, yang seyogyanya merupakan instrumen untuk menilai capaian kerja. Hal ini juga berimbas pada sulitnya meningkatkan jumlah PNS perempuan menduduki jabatan pimpinan tinggi (kasmir, 2018).

\section{b. Perilaku Kerja}

Disamping SKP, indikator penilaian prestasi kerja menurut PP 30 Tahun 2019 adalah perilaku kerja. Untuk mengukur perilaku kerja ini pemerintahan tertentu menggunakan istilah peer review $360^{\circ}$. yang merupakan instrumen penilaian terhadap seorang PNS atas kinerja dan perilaku kerjanya termasuk kemampuan dalam bekerjasamanya. peer review $360^{\circ}$ ini dilakukan secara tertutup, PNS yang dinilai tidak mengetahui siapa saja yang rekan dan bawahan yang menilai perilakunya.

Peer review $360^{\circ}$, merupakan metode yang dianggap fair atau adil untuk menilai seseorang untuk menduduki posisi jabatan terutama bagi PNS perempuan yang selama ini diposisikan pada kelas ke- 2 setelah laki-laki dalam meraih karir, karena adanya stereotipe bahwa ranah publik adalah area kerja laki-laki termasuk di birokrasi pemerintahan.

Hasil menunjukkan penggunaan peer review sebagai indikator untuk promosi jabatan pada jabatan administrator dan pemimpin tinggi pratama (eselon II dan III) belum dapat meningkatkan presentase perempuan yang menduduki jabatan diposisi jabatan tersebut. Hal ini dapat dilihat dari perbandingan jumlah laki-laki dan perempuan yang menduduki jabatan eselon II dan III masih cukup senjang. Pejabat perempuan pada eselon III hanya $25 \%$ dan eselon II hanya $10 \%$ dari total jumlah pejabat di eselon III dan II baik laki-laki maupun perempuan (Ibrahim, 2013).

\section{Senioritas}

Secara umum, senioritas masih digunakan pada organisasi publik maupun swasta sebagai dasar untuk promosi jabatan, meskipun bukan menjadi indikator utama. Bagi PNS, senioritas diartikan sebagai pengakuan akan lamanya masa kerja baik pada jabatan maupun masa kerja scecara keseluruhan pada organisasi. Untuk promosi jabatan, kelihatannya senioritas tidak lagi dapat menjamin bahwa seorang pegawai mampu dan kompeten. 
Sebagai gambaran bahwa senioritas bukan menjadi hal utama yang dipertimbangkan, seperti bisa kita lihat dari masa kedua pejabat struktural perempuan tersebut di pemerintahan daerah Jawa Barat, dimana Kabag Adm Keuangan \& Perencananaan pada saat ini berusia 51 tahun, memiliki masa kerja 31 tahun, beliau masih menduduki jaabatan administrator/eselon III a, sedangkan Kabag Pengelola lpse Biro Barjas berusia 45 tahun dengan masa kerja 26 tahun, menduduki jabatan pada eselon yang sama (Hartati, 2020).

Senioritas pegawai dalam suatu organisasi bukan hanya diukur dari usia dan lama masa tugas atau jabatan, akan tetapi juga dari pangkat/golongan. PNS yang lebih tinggi pangkat/golongan dapat dikatakan senior, meskipun usianya lebih muda dari pegawai yang pangkat/golonganya rendah. Untuk melihat lebih jelasnya perhatikan gambar dibawah ini:

\begin{tabular}{|c|c|c|c|c|c|c|}
\hline \multirow{3}{*}{ Golongan Kepangkatan2 } & \multicolumn{6}{|c|}{ Jumlah PNS Menurut Golongan Kepangkatan dan Jenis Kelamin (Jiwa) } \\
\hline & \multicolumn{2}{|c|}{ Laki-laki } & \multicolumn{2}{|c|}{ Perempuan } & \multicolumn{2}{|c|}{ Laki-laki + Perempuan } \\
\hline & 2019 & 2020 & 2019 & 2020 & 2019 & 2020 \\
\hline I/A (Juru Muda) & 7,00 & 5,00 & - & - & 7,00 & 5,00 \\
\hline I/B (Juru Muda Tk.I) & 26,00 & 27,00 & 3,00 & 1,00 & 29,00 & 28,00 \\
\hline I/C (Juru) & 206,00 & 114,00 & 23,00 & 17,00 & 229,00 & 131,00 \\
\hline $\mathrm{I} / \mathrm{D}$ (Juru TK,I) & 188,00 & 217,00 & 11,00 & 15,00 & 199,00 & 232,00 \\
\hline Golongan I & 427,00 & 363,00 & 37,00 & 33,00 & 464,00 & 396,00 \\
\hline II/A (Pengatur Muda) & 462,00 & 299,00 & 72,00 & 45,00 & 534,00 & 344,00 \\
\hline II/B (Pengatur Muda Tk.I) & 835,00 & 669,00 & 315,00 & 258,00 & 1150,00 & 927,00 \\
\hline II/C (Pengatur) & 2307,00 & 1796,00 & 1263,00 & 938,00 & 3570,00 & 2734,00 \\
\hline II/D (Pengatur TK.I) & 1181,00 & 1608,00 & 843,00 & 1029,00 & 2024,00 & 2637,00 \\
\hline Golongan II & 4785,00 & 4372,00 & 2493,00 & 2270,00 & 7278,00 & 6642,00 \\
\hline III/A (Penata Muda) & 1959,00 & 1794,00 & 2028,00 & 1832,00 & 3987,00 & 3626,00 \\
\hline III/B (Penata Muda TK.I) & 3260,00 & 2888,00 & 3144,00 & 2844,00 & 6404,00 & 5732,00 \\
\hline III/C (Penata) & 4078,00 & 3795,00 & 4670,00 & 4342,00 & 8748,00 & 8137,00 \\
\hline III/D (Penata Tk.I) & 3553,00 & 3613,00 & 4220,00 & 4592,00 & 7773,00 & 8205,00 \\
\hline Golongan III & 12850,00 & 12090,00 & 14062,00 & 13610,00 & 26912,00 & 25700,00 \\
\hline IV/A (Pembina Muda) & 3208,00 & 2998,00 & 2604,00 & 2571,00 & 5812,00 & 5569,00 \\
\hline IV/B (Pembina Muda Tk.I) & 4309,00 & 3844,00 & 3981,00 & 3694,00 & 8290,00 & 7538,00 \\
\hline IV/C (Pembina) & 391,00 & 384,00 & 291,00 & 301,00 & 682,00 & 685,00 \\
\hline IV/D (Pembina Tk.I) & 97,00 & 101,00 & 50,00 & 64,00 & 147,00 & 165,00 \\
\hline IV/E (Pembina Utama) & 36,00 & 37,00 & 12,00 & 14,00 & 48,00 & 51,00 \\
\hline Golongan IV & 8041,00 & 7364,00 & 6938,00 & 6644,00 & 14979,00 & 14008,00 \\
\hline Jumlah & 26103,00 & 24189,00 & 23530,00 & 22557,00 & 49633,00 & 46746,00 \\
\hline
\end{tabular}

Gambar 1. Jumlah PNS menurut golongan kepangkatan dan jenis kelamin (jiwa)

Sumber: https://jatim.bps.go.id/indicator/101/111/1/jumlah-pns-menurutgolongan-kepangkatan-dan-jenis-kelamin.html

Data pada gambar diatas, menunjukkan dari aspek kepangkatan/golongan ternyata PNS laki-laki secara umum mempunyai tingkatan pangkat/golongan (I/a - V/e) lebih banyak daripada perempuan. Hal ini wajar, karena dari sisi jumlah, PNS laki-laki lebih banyak perempuan. Hanya pada golongan III/a, III/b dan III/d jumlah PNS perempuan lebih banyak dari jumlah PNS laki-laki. 


\section{Kompetensi}

Dasar pertimbangann promosi jabatan menurut UU Nomor 5 Tahun 2014 pasal 72 adalah kompetensi. Untuk duduk di dalam suatu jabatan struktural pemerintahan, bahwa kompetensi menjadi dasar pertimbangan utama. Adapun kompetensi yang harus dimiliki oleh seorang PNS untuk dapat menduduki suatu jabatan menurut PP No. 11 Tahun 2017 dan Pergub 58 Tahun 2018, berupa: kompetensi teknis, kompetensi manajerial, kompetensi sosial kultural dan pemerintahan

Kompetensi ini harus dilakukan dengan sertifikat diantaranya: Sertfikat Diklat Kepemimpinan, Diklat Barang dan Jasa dan Diklat teknis lainnya. Untuk mendapatkan PNS yang kompeten perlu melalui pendidikan atau latihan (Diklat). Tingkat kompetensi PNS perempuan di jabatan birokrasi, hanya dapat dipotret dari perbandingan data jumlah yang menduduki jabatan struktural dengan alumni Diklat sebagaimana gambar dibawah ini:

\begin{tabular}{|c|c|c|c|c|c|c|c|}
\hline \multirow{3}{*}{ Jabatan + Jumlah } & \multicolumn{7}{|c|}{ Jumlah Pegawai Negeri Sipil Menurut Jabatan dan Jenis Kelamin (Orang) } \\
\hline & \multicolumn{3}{|c|}{ Laki-Laki } & \multicolumn{3}{|c|}{ Perempuan } & \multirow[b]{2}{*}{2014} \\
\hline & $2014^{\pi}$ & 2015 & 2016 & 2014 & 2015 & 2016 & \\
\hline Fungsional Tertentu & 933297 & 920318 & 901285 & 1395527 & 1391830 & 1383578 & 2328824 \\
\hline $\begin{array}{l}\text { Fungsional } \\
\text { Umum/Staff }\end{array}$ & 1138896 & 1199314 & 1015197 & 675727 & 740518 & 640492 & 1814623 \\
\hline Struktural & 216438 & 216029 & 301011 & 95418 & 90416 & 132786 & 311856 \\
\hline Eselon V & 7096 & 4908 & 9992 & 3110 & 2378 & 4538 & 10206 \\
\hline Eselon IV & 144469 & 148304 & 199886 & 75724 & 73674 & 105901 & 220193 \\
\hline Eselon III & 52682 & 51507 & 72957 & 14163 & 12654 & 19495 & 66845 \\
\hline Eselon II & 11707 & 10928 & 17592 & 2295 & 1639 & 2724 & 14002 \\
\hline Eselon I & 484 & 382 & 584 & 126 & 71 & 128 & 610 \\
\hline Jumlah & 2288631 & 2335661 & 2217493 & 2166672 & 2222764 & 2156856 & 4455303 \\
\hline
\end{tabular}

Gambar 2. Jumlah PNS menurut jabatan dan jenus kelamin (orang)

Sumber: https://www.bps.go.id/indicator/101/666/1/jumlah-pegawai-negerisipil-menurut-jabatan-dan-jenis-kelamin.html

Data diatas menunjukkan bahwa PNS laki-laki lebih banyak dari jumlah PNS perempuan. Jika dilihat dari setiap jenjang eselon, maka kesenjangan yang paling tinggi ada pada jabatan pimpinan tinggi pratama (eselon I). PNS perempuan hanya menduduki jabatan sekitar $10 \%$.

Salah satu penyebab rendahnya persentase perempuan menduduki jabatan struktural disebabkan oleh rendahnya tingkat kompetensi PNS perempuan yang mengikuti Diklat dan kegiatan peningkatan kompetensi lainnya. Hal ini membenarkan teori patriarki yaitu dominasi kaum laki-laki juga berlangsung pada tingkat sosial 
dimana laki-laki memegang posisi kekuasaan politik, sosial, ekonomi dan kehidupan kerja (Hartati, 2020).

Terlepas pada teori patriarki pada tahun 2020 tingkat jabatan PNS perempuan mengalami kenaikan yang signifikan terlihat pada gambar dibawah ini:

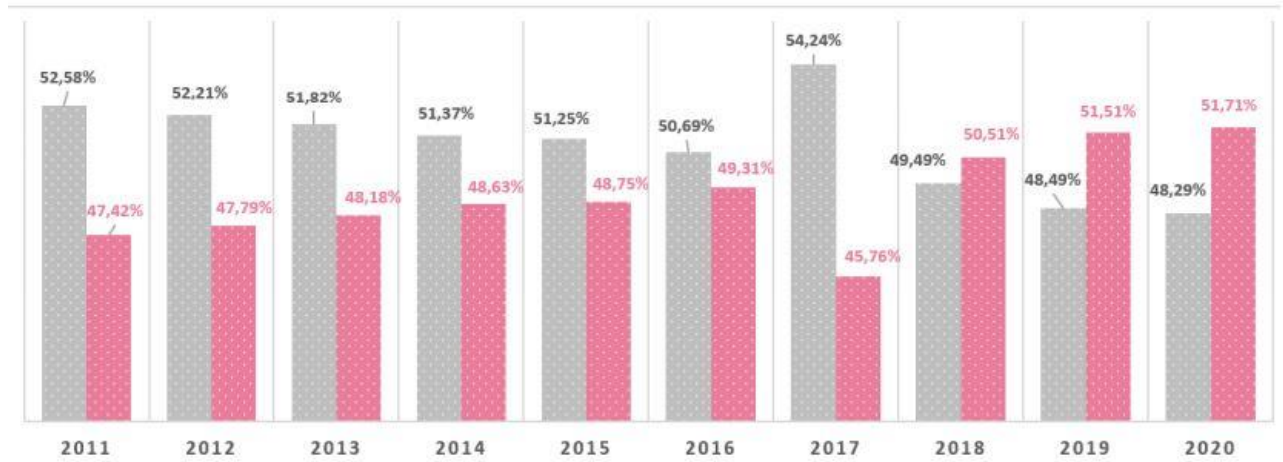

Gambar 3. Data PNS tahun 2011 sampai tahun 2021

Sumber: Buku Statistik PNS Juni 2020

PNS perempuan mengalami peningkatan dari tahun 2018 meningkat menjadi 0,20\% dibanding pada tahun 2019. Total PNS pria sebanyak 1.990 .215 atau $48,29 \%$ sedangkan total PNS perempuan sebanyak 2.130.961 atau sekitar 51,71\%. Hal ini membutikkan kesetaraan gender terhadap PNS perempuan yang memiliki dan menduduki kesempatan berpartisipasi dibidang birokrasi pemerintahan (BPS, 2020).

\section{Kualifikasi}

Dasar pertimbangan promosi jabatan menurut UU No.5 Tahun 2014 pasal 72 tentang kualifikasi. Kualifikasi merupakan kehalian yang diperlukan oleh seorang PNS untuk melakukan sesuatu pekerjaan atau jabatannya. kualifikasi diperoleh melalui pendidikan formal. Salah satu penyebab rendahnya jumlah PNS perempuan yang menduduki jabatan struktural, karena dari sisi kualifikasi PNS perempuan lebih rendah dibandingkan PNS laki-laki, terutama pada jenjang pendidikan S2 dan S3.

Upaya untuk meningkatkan kualifikasi PNS sudah dilakukan dengan mengirimkan tugas belajar dan memberikan izin belajar bagi pns. Jika melihat formasi tugas belajar, PNS perempuan memiliki kesempatan untuk bersaing dengan PNS lakilaki untuk mendapatkannya. Tugas belajar bagi PNS perempuan akan lebih memberikan keuntungan karena perempuan dapat lebih fokus menjalani pendidikan tanpaharus terbebanitugas pokoknya dikantor.

Pada beberapa kasus, PNS perempuan menghadapi kendala kurang rasa percaya diri untuk menunjukkan kemampuan dirinya apabila berada didalam suatu kelompok. 
Perkembangan zaman turut mempengaruhi kadar budaya patriarki. semakin ke kota, nilai-nilai yang menomorsatukan laki-laki dan menomorduakan perempuan semakin berkurang kadarnya. Hal ini tentu dipengaruhi oleh cara pandang masyarakat yang berbeda dan cara pandang ini dipengaruhi oleh tingkat pendidikan dan wawasan yang dimiliki oleh masyarakat tersebut.

Dalam konteks promosi jabatan, maka seseorang memiliki peningkatan tugas dan wewenang sehingga konsekuensinya menyita banyak waktu terlbih bagi pns perempuan. Keputusan perempuan untuk tidak menerima psosisi jabatan yang ditawarkan demi kepentingan keluarga bukanlah menunjukkan bahwa perempuan lema, akan tetapi dia merasa bahwa tetap bisa memberikan kontribusi bagi pembangunan dengan menjaga stabilitas keluarga, mendidik dan memilihara anak-anaknya sebagai penerus bangsa yang berkualitas. Berbanding terbalik dengan cara pandang feminisme dan patriarki, mereka melihat ini sebagai ketidakadilan gender atau gender mainstream (Hartati, 2020).

\section{Simpulan}

PNS perempuan memiliki tingkat partsipasi dalam struktur birokasi pemerintahan lebih tinggi dibandingkan PNS laki-laki yang ditandai dengan peningkatan partisipasi PNS perempuan pada tahun 2020 mencapai total 2.130.961 atau sekitar 51,71\%, sedangkan partisipasi PNS laki-laki hanya sebanyak 1.990.215 atau $48,29 \%$, yang berarti hal ini membutikkan adanya kesetaraan gender terhadap PNS perempuan untuk memiliki kesempatan berpartisipasi dalam birokrasi pemerintahan, akan tetapi kesetaraan gender belum sepenuhnya tercapai karena masih terjadi kesenjangan dalam promosi jabatan pada birokrasi pemerintahan dimana PNS perempuan masih sulit untuk mendapatkan jabatan pimpinan tertinggi dikarenakan adanya beberapa faktor penyebab, antara lain, dari segi kompetensi, tingkat partisipasi PNS perempuan yang mengikuti Diklat dan kegiatan kompetensi lainnya masih rendah dibandingkan PNS laki-laki, padahal untuk mencetak PNS yang berkompeten perlu melalui pendidikan atau pelatihan (Diklat). Selain itu, dari segi kualifikasi, PNS perempuan masih lebih rendah dari PNS laki-laki terutama pada jenjang pendidikan S2 dan S3. Pada beberapa temuan kasus, PNS perempuan memiliki kendala rasa kurang percaya diri untuk menunjukkan kemampuan dirinya dalam suatu kelompok. 


\section{DAFTAR PUSTAKA}

BPS. (2020). Buku Statistik PNS Juni 2020. Jakarta: Badan Kepegawaian Negara

Hartati, S. (2020). Gender Dalam Birokrasi Pemerintahan. Surabaya: PT Scopindo Media Pustaka

https://www.bkn.go.id/berita/perempuan-pejabat-struktural-di-birokrasi-lebih-sedikitdaripada-laki-laki

https://jatim.bps.go.id/indicator/101/111/1/jumlah-pns-menurut-golongan-kepangkatandan-jenis-kelamin.html

https://www.bps.go.id/indicator/101/666/1/jumlah-pegawai-negeri-sipil-menurutjabatan-dan-jenis-kelamin.html

https://bps.go.id/indikator/indikator/view_data_pub/0000/api_pub/TEJrTHhZODZmSX hoblFvSGtlbkFMQT09/da_02/1

Ibrahim. (2013). Bias Gender Dalam Birokrasi. Yogyakarta: Tiara Wacana

Lexy J, Moeleong. (2008). Metode Penelitian Kualitatif. Bandung: Remaja Rosdakarya

Kadarisman, M. (2013). Manajemen Pengembangan Sumber Daya Manusia. Jakarta: PT. Raja Grafindo Persada

Kasmir. (2018). Manajemen Sumber Daya Manusia (Teori dan Praktik). Depok: PT. Raja Grafindo Persada

Salalahi, U., racjmawati, T., Bernadus, S. E. (2016) Kesetaraan Gender Dalam Administrasi Publik: Peluang Pegawai Perempuan Dalam Promosi Jabatan Di pemerintah Kota Bandung. Lppm Unpar.

Sahirah, Burhanuddin. (2015). Pengarusutamaan Gender Dalam Promosi Jabatan Di BKD Pemerintahan Kota Makassar. Jurnal Administrasi Politik

Sari, I. L., Raharjo, A. P., \& Rahmawati, D. N. (2018). Pembangunan Manusia Berbasis Gender. Jakarta: KEMENPPA

Zed, Mestika. (2008). Metode Penelitian Kepustakaan. Jakarta: Yayasan Obor Indonesia. 